\title{
IDENTITY AND SYMBOLS IN THE CULTURAL SPACE OF THE HUMAN BEING
}

\section{Volodymyr Pylypiv}

\section{INTRODUCTION}

The individual and society's knowledge and awareness of the history of world culture significantly affect the interpretation of the world, thus contributing to the emergence of various options for social action and social relations. Such a conglomeration is a social repertoire, or vision of a person's cultural instruments ${ }^{1}$. Therefore, people develop their own life strategies.

Powerful preparation for social interaction and the availability of several strategies increase a person's confidence and ability to collective action and to social justice. Social justice is a concept that defines honest and fair relationship between person and society. It is measured by the explicit and latent conditions for the distribution of wealth, opportunities and social privileges. Social justice includes our deepest beliefs about the world and the life we want for ourselves and others, formed by politics, religion, ethnicity and a sense of identity ${ }^{2}$.

Meeting with different cultures can confirm existing beliefs, cause misunderstandings, anxiety, or even aggression, or broaden life horizons. Certain cultural models may reflect conflict situations and, at the same time, offer possible solutions ${ }^{3}$.

The new ideas perception, the world's new interpretation formation, the awareness of the options' diversity for social actions and relationships contribute to a deeper awareness of one's own cultural identity, which involves a sense of self-identification to a particular culture, the adoption of certain cultural norms, patterns of behaviour, value orientations and the like.

\section{Symbols are an integral part of the human world}

We live in a world of complex symbolism, with deep cultural roots symbols being modified, edited and compared to each other thus creating the

${ }^{1}$ Swidler, A. (1998). Culture and Social Action. In Ph. Smith (Ed.). The New American Cultural Sociology. Cambridge, U.K.: Cambridge University Press (pp. 17-187).

2 Salata, G. (2019). Bibliotekoznavstvo, informatsiini nauky ta sotsialna spravedlyvist. Ukrainian Journal on Library and Information Science, 3, 10-18. DOI: http://dx.doi.org/ 10.31866/2616-7654.3.2019.169662.

${ }^{3}$ Danylova, T. (2013). Overcoming the Cultural Differences: Parable as a Means of Intercultural Dialogue. Anthropological Measurements of Philosophical Research, 3, 42-51. 
new ones. Graphic designers often interpret cultural symbols with graphic identities.

The symbolic languages of the worlds of technology, law, games, and sports can transform a symbolic meaning into a brand due to the graphic identity built on the symbol of one of these subcultures. Social institutions, economics and culture may be unfair as such. In trying to achieve social justice, it is necessary to remember the importance of deep-seated social and cultural factors, as well as to understand how they shape the life prospects of individuals and communities. An indispensable component is the care of individual members of the community, respect for their inner world ${ }^{4}$.

Our world is saturated with symbols that are everywhere: on flags fluttering in the air, cars, tattoos on the body. Even memes turn into a symbol. As a rule, symbols are not noticed until they are used consciously or receive a negative connotation. In a significantly image-oriented culture, understanding of symbols and symbolism in general can help us to understand the nuances of our visual world.

Symbols are presented in various forms: verbal and non-verbal, written and unwritten. They are everything that conveys meaning, such as words, pictures, gestures. Clothes, homes, cars and other commodities turn into symbols identifying a certain level of social status. The symbols are culturally specific and give meaning to the world around them.

Since symbols cover both material and non-material dimensions of human life, no aspect of human experience can escape their universal reality. However, some symbols are much more common than others and are immediately identified by most people. Although they do not cause the identical feelings in everybody, hardly anyone can ignore them.

Symbols shape social reality. Often, symbols are associated with a value system of culture, which, in turn, affects people's lifestyles, goals, aspirations, and motivation to act. A separate group of symbols are cultural ones representing a certain cultural reality ${ }^{5}$. Each culture has its own set of symbols associated with different experiences and perceptions ${ }^{6}$.

These symbols contribute to a sense of belonging and cultural uniqueness. Representatives of each cultural group should correctly interpret and rethink

${ }^{4}$ Salata, G. (2019). Bibliotekoznavstvo, informatsiini nauky ta sotsialna spravedlyvist. Ukrainian Journal on Library and Information Science, 3, 10-18. DOI: http://dx.doi.org/10.31866/2616-7654.3.2019.169662.

${ }^{5}$ Danylova, T. (2018). Between the Land, Sea, and Sky: Some Words on the Art of the Minoan Civilization of Bronze Age Crete. Interdisciplinary Studies of Complex Systems, 13, 107-116. [in English].

${ }^{6}$ Danylova, T.V. (2016). The Theory of Civilizations Through the Lens of Contemporary Humanities. Anthropological Measurements of Philosophical Research, 9, 55-62. DOI: 10.15802/ ampr2016/72231. [in English]. 
their symbols over time. On this basis, it seems relevant to study a number of issues, including a thorough analysis of the phenomenon of the symbol in the multi-layered model of culture (the onion model of culture).

Cultural identity is a major value factor in the development of ethnically diverse societies. By influencing the processes of integration and disintegration, cultural identity simultaneously functions as an indicator of the internal state of the multi-ethnic community as a socio-cultural system.

The concept of cultural identity is constantly drawing the attention of scholars. It needs a deep, multifaceted study from theoretical, methodological, and ontological positions.

Its development depends on the scientific orientation of the researchers and the basic assumptions about the nature and history of cultural identity. A modern person is a representative of different cultures interacting and influencing one another at the level of countries, regions, religions, organizations, social groups, families and the like. The diversity of membership patterns across groups is likely to hinder the formation of a single culture, shared by all group members. Even one individual will "change" within the accepted culture. Cultural exchange includes three aspects, such as mental models, preferences, and artifacts. Mental models are the knowledge, beliefs, and procedures that help members of a particular group interact with the outside world. Culture has a significant impact on mental models and related systems of thought ${ }^{7}$.

Social and scientific approaches conceptualize cultural identity as a process of "social categorization" based on both individual choice and the relationship between an individual and the group / groups ${ }^{8}$.

Interpretive cultural approaches consider cultural identity as a social and cultural construct that depends not only on a person, but is dynamically created, discussed and enhanced in the process of interaction with representatives of in-groups and out-groups ${ }^{9}$.

The critical approach representatives regard cultural identity as an "ideological" construction and power structures representation ${ }^{10}$.

${ }^{7}$ Salata, G.V., Bachynsjka, N.A. (2019). Kultura i komunikatsiia: yak kultura vplyvaie na spryiniattia informatsii. Bibliotekoznavstvo. Dokumentoznavstvo. Informologhija, 3, 80-87.

${ }^{8}$ Berry, J.W. (1980). Introduction to methodology. In H.C. Triandis \& J.W. Berry (Eds.). Handbook of cross-cultural psychology, 1. Boston: Allyn and Bacon (pp. 1-28).

${ }^{9}$ Collier, M., \& Thomas, M. (1988). Identity in intercultural communication: An interpretive perspective. In Y.Y. Kim \& W.B. Gudykunst (Eds.). Theories in intercultural communication (International and Intercultural Communication Annual), 12. Newbury Park, CA: SAGE 12 (pp. 99-120).

${ }^{10}$ Shin, C.I. \& Jackson, R.L. (2003). A review of identity research in communication theory: Reconceptualizing cultural identity. In W. J. Starosta \& G.-M. Chen (Eds.). Ferment in the Intercultural Field: Axiology/Value/Praxis. Thousand Oaks, CA: SAGE (pp. 211-241). 
The history of culture in general and culture in particular, is a conditioned way of individual or collective behaviour, based on the past and projected into the future. The history of culture is cyclical. The cultural specificity of a nation is a set of historical, prehistoric factors, and the national psyche is a mysterious force hidden in national customs, oral traditions and language.

Beyond our conscious perception it is the power motivating our behaviour and triggering our impulses. The implicit, volatile and often uncertain national character is manifested in all aspects of the nation's life - both in historical achievements and in tragedies.

Cultural identity is based on the social experience of a society, it is objectified and institutionalized in a way of life been characteristic for the members of the defined community, differentiating it from another community's lifestyle and making it unique.

Artifacts are cultural manifestations in the material world that confirm the mental models and preferences of a particular cultural group's members. Artifacts are visible manifestations of culture, especially for representatives of other cultures. They are a key channel through which mental models and values are broadcast. Cultures differ significantly in their degree of influence on a particular group. The inclusiveness and power of culture are those aspects of cultural exchange that particularly affect the information space. The inclusiveness of culture implies the level of its influence on all aspects of individual behaviour. A strong culture universally manifests its core values, and common artifacts must be respected by all members of the group. Instead, a weak culture demonstrates a rather high level of differences between group members in observing the common elements ${ }^{11}$.

Such Ukrainian scientists as S. Storozhuk, Y. Hoyan ${ }^{12}$, V. Shynkaruk ${ }^{13}$, L. Shynkaruk ${ }^{14}$, G. Salata ${ }^{15}$, T. Danylova ${ }^{16}$, V. Pylypiv ${ }^{17}$ also paid attention to

${ }^{11}$ Salata, G.V., Bachynsjka, N.A. (2019). Kultura i komunikatsiia: yak kultura vplyvaie na spryiniattia informatsii. Bibliotekoznavstvo. Dokumentoznavstvo. Informologhija, 3, 80-87.

${ }^{12}$ Storozhuk, S. V., Hoyan, Y.N. (2016). Vplyv virtualnoi realnosti na samoaktualizatsiiu tyneidzheriv: antropolohichnyi vymir. Anthropological Measurements of Philosophical Research, 9, 17-28. DOI: 10.15802/ ampr2016/72119.

${ }^{13}$ Shynkaruk, V., Salata, G. \& Danylova, T. (2018). My thas the Phenomenon of Culture. Academy of Managerial Staff of Culture and Arts Herald, 4, 17-22.

${ }^{14}$ Shynkaruk, L., Salata, G. \& Danylova, T. (2018). Dialogue of Cultures: E. Hall and F. Kluckhohn. Academy of Managerial Staff of Culture and Arts Herald, 3, 128-133.

${ }^{15}$ Salata, G. \& Danylova, T. (2018). The Ecological Imperative and Human Nature: A New Perspective on Ecological Education. Interdisciplinary Studies of Complex Systems, 12, 17-24.

${ }^{16}$ Danylova, T. (2015). The Way to the Self: The Novel "Steppenwolf" Through the Lens of Jungian Process of Individuation. Anthropological Measurements of Philosophical Research, 7, 28-35.

${ }^{17}$ Pylypiv, V. (2019). Arkhetypni kulturni symvoly ta formuvannia kulturnoi identychnosti ukraintsiv Kanady: do postanovky problemy. National Academy of Managerial Staff of Culture and Arts Herald, 1, 190-194. DOI: https://doi.org/10.32461/2226-3209.1.2019.166907. 
the study of cultural identity as a necessary component of individual and collective identity. However, the concept of cultural identity requires a thorough development, a closer attention of Ukrainian researchers to this phenomenon.

Culture is a conglomeration of cognitive and evaluative beliefs / ideas about desirable reality that are detailed in values, institutions, and norms ${ }^{18}$. Culture can be interpreted as denotative, connotative and pragmatic knowledge shared by a certain group with a common history and participating in the society structuring ${ }^{19}$.

Culture is not an abstract concept - it is "embedded" in the realities of everyday life. In fact, culture cannot be separated from the social realities in which it develops, or from the people who are both its creators and creations. For a deeper understanding of culture and avoiding simplified interpretations, it is necessary to take into account the social realities, political, geographical, demographic and economic aspects of society.

The history of Ukrainian culture ... like any other, imbued with symbols that transmit its meaning from one generation to the next. Culture symbols can be of two types - external and internal, that is, visible and patterns of behaviour or results of behaviour, perceived by others. These include dances, diaspora members' gatherings, pictorial and linguistic presentations, art objects and more.

Although internal symbols are usually transmitted through external symbols, they are cognized intelligently or intuitively, not merely conceived. These include beliefs, values, feelings and ideas, for example, religious beliefs, political or social values, such as the value of democracy; legends, mythology, or a particular group history and a group self-identification sense.

Preserving ethnic identity across generations does not necessarily mean preserving all the characters contained in the culture. In fact, the ubiquity of a culture does not mean that all its symbols are equally significant or accepted by all members of the community. People selectively use cultural symbols. This is especially true of different generations living in a culturally diverse environment ${ }^{20}$.

Although many claim that we are now living in an age of text, our active use of symbolic images proves another thing. Symbols are the basis of culture.

${ }^{18}$ Kemper, D. (1993). Sociological Models in the explanation of emotion. In M. Lewis \& J.M. Havilland (Eds.). Handbook of Emotions. New York: The Guilford Press (pp. 41-51).

${ }^{19}$ Swidler, A. (2003). Talk of Love; How Culture matters. Chicago, Il: University of Chicago Press (pp. 250-285).

${ }^{20}$ Pylypiv, V. (2019). Arkhetypni kulturni symvoly ta formuvannia kulturnoi identychnosti ukraintsiv Kanady: do postanovky problemy. National Academy of Managerial Staff of Culture and Arts Herald, 1, 190-194. DOI: https://doi.org/10.32461/2226-3209.1.2019.166907. 
A symbol is an object, word, or action full of hidden meanings not rooted in the natural world, but in the world of culture. Human life and human interaction are based on cultural symbolism and manifest through it. Symbols mean different things to different people; some are from experience, others are from culture.

Symbolic representation has been inherent in humanity throughout history. Different clans and tribes had their own symbolism, with which they decorated their banners, shields and clothes. These symbols contained the meanings, people attached to certain shapes, colours, textures, and images. All this was used in the process of communicating with other clans and tribes thus identifying the designated cultural group by certain symbolic images.

A symbol is defined as anything that has a specific meaning and the meaning is recognized by a particular culture representatives ${ }^{21}$. Symbols help members of one culture to understand what other parties are doing ${ }^{22}$.

The perception, interpretation, and experience of using symbols vary across cultures. Therefore, symbols can be of special meaning for people sharing the same culture and not have a deep semantic load for members of other cultures, while not causing a negative reaction.

For example, on the first day of Chinese New Year, the Chinese tend to dress bright in colours such as red, believing that bright colours bring happiness, prosperity and good luck throughout the year. However, this custom is not mandatory for other cultural groups. Today, the cultural speech of mankind includes more and more visual forms of communication. Even the use of characters begins to change ${ }^{23}$.

Interpreting the specific character of the symbol, A. Losev highlighted its natural decomposition into many reincarnations, which is to be the most original feature of the symbol. According to the philosopher, the symbol of a thing, though being its reflection, actually contains much more than the thing itself, since we perceive every thing as it is at the moment. Instead, the hidden symbol contains all possible manifestations of a thing. It is this extraordinary generalization and ideological richness that make it the basis of culture ${ }^{24}$.

Thus, the symbol acts as the principle of constructing a thing or phenomenon, providing them with a deeper meaning. A symbol generates a thing or phenomenon, shaping their internal pattern. This generation is only a penetration into the deep and natural basis of the very things presented in the

\footnotetext{
${ }^{21}$ Macionis, J. (2005). Sociology. Pearson Prentice Hall.

${ }^{22}$ Peoples, J. \& Bailey, G. (2017). Humanity: An Introduction to Cultural Anthropology. Cengage Learning.

Unger, J. (2018). Symbols and Symbolisms in Culture. Papyrus. URL: http://papyrus.greenville.edu/ 2018/02/symbols-and-symbolisms-in-culture.

${ }^{24}$ Losev, A.F. (1995). Problema symvolu ta realistychnoho mystetstva. Moscow: Iskusstvo.
} 
sensual reflection, only very vague, uncertain and chaotic ${ }^{25}$. The symbol combines single things into certain integrity, fixing it in cultural code and transmitting it to subsequent generations.

Symbols give rise to a deep sense of existence, elevates man above the "world of consumption". Symbols cannot be interpreted within the framework of formal logic because they appeal to instincts, affects and emotions; they provide opportunities to comprehend life, because life itself gives rise to emotions and symbolic ideas.

In the process of comprehending a symbol, we should take into account not only the symbol itself, but also the uniqueness of the culture that generated it. It is important for anthropologists to consider their own cultural background while studying symbolism in a different culture. This is because many symbols, although similar in appearance, can have different meanings.

These symbols need to be interpreted through the prism of the particular culture to which they refer; otherwise they may lose their unique meaning. One example of a misinterpreted cultural symbol is the swastika symbol, which is a long-standing solar symbol, spread from India to America. Because it looks almost identical to the Nazi swastika, it provokes a negative reaction in many people.

Cultural symbols are commonly used to express "eternal truths". They go a long way in transforming and acquiring conscious characteristics, gradually obtaining the qualities of collective images adopted by a particular culture. Symbols that are part of human culture retain a significant charge of their original energy, causing some people to have a strong emotional response.

This original energy is fully manifested in natural symbols, arising from the subconscious content of the psyche and representing innumerable variations of the basic archetypal images. In many cases, they can be traced back to their original roots, that is, ideas and images found in ancient sources that came from primitive societies ${ }^{26}$.

Language is the most commonly used form of symbolism. There are 6,912 living languages known, with their diversity been caused by some isolation. Most languages have their own "symbols" to indicate each letter, word or phrase. Using a language is adaptive: for example, there are two language groups in contact with each other it causes a need of finding ways of communication.

They create a language that has a great deal of flexibility in using language symbols (sound models) or a hybrid set of symbols for transmitting messages. This contact language - the pidgin - eventually gives way to the creole

\footnotetext{
${ }^{25}$ Losev, A.F. (1995). Problema symvolu ta realistychnoho mystetstva. Moscow: Iskusstvo, p. 47.

${ }^{26}$ Yunh, C.G. (1991). Arkhetip i simvol. Moscow: Renessans, p. 84.
} 
language with a more formal set of symbols (words), grammatical rules for organizing them, as well as their own native speakers transmitting language from generation to generation.

Language is the key to the world of culture and a system of symbols that allows people to communicate with one another. The sense-creative function of symbols forms a single cultural space of a particular group, promotes cultural identification, produces a common meaning, provides guidelines for individual existence, and transmits cultural values into the future. The symbols' usage is adaptive. This means that people can learn to associate new characters with an established concept or a new concept with a familiar symbol.

\section{Basic approaches to understanding the phenomenon of culture}

There are different approaches to understanding the phenomenon of culture. The essentialist point of view is based on the idea that culture is conditional and static, it has fixed characteristics, and differences between representatives of one culture are considered secondary.

In a globalized world where people often migrate, travel both physically and virtually, live in constant interaction with other cultures, this approach is considered to be irrelevant. Moreover, such a reductionist view of culture restricts human understanding only to the theories and methodologies not corresponding the realities of the XXIst century.

But the constructivist approach defines culture as a multi-faceted dynamic phenomenon being in continuous evolution. From the constructivism's point of view, culture is defined through interaction between people; being fluid, it constantly evolves and adapts to new realities.

Thus, culture develops and changes over many years; it is affected by the interaction of its members with members of other cultures and with their environment, as well as cultural and economic exchange and globalization.

This type of discourse interprets culture as a process that is multifaceted and diverse in its values, beliefs, practices, and traditions, some of which may be completely new. Thus, from this point of view, culture is negotiable, giving opportunities for personal choice, social justice, and a dynamic process whereby the arrangements and boundaries of groups or communities are revised in accordance with current needs ${ }^{27}$.

Combating social exclusion, implementing the principle of social justice is one of the important factors in the history of postmodern world culture. Social justice is a concept that defines a fair and honest relationship between man and society. It is measured by the explicit and latent conditions for the

27 Intercultural Learning: theories, contexts, realities. (2009). URL: https:// pjp-eu.coe.int/documents/1017981/10762748/Ch2.pdf/0b364432-7efb-6a45-a4bc-50de19787213. 
distribution of wealth, opportunities and social privileges. Social justice includes our deepest convictions, shaped by cultural identity, politics, religion, ethnicity, and a sense of identity ${ }^{28}$.

Our perception of culture influences the interpretation of cultural reality, our interaction with others, and the way we understand our identity and that of others. Of course, culture is not the answer to every question, but it is an important aspect that shapes our worldview and our interpretations, along with other aspects such as living conditions, gender, sexual orientation, social and economic status, etc.

In the context of culture, like many other dimensions, identity is constantly being built, and the process of the role's acceptance and fulfilment, mediated by external (social, political) and internal (psychological, emotional) aspects, lasts throughout life ${ }^{29}$.

A fluid cultural identity can be understood as the unification of two identities - individual and group - into one. Thus, cultural identity is always in the process, it is never a complete fact ${ }^{30}$.

If we consider our identity as static, ascriptive, we are inclined or forced to conform to a certain system of expectations regarding cultural norms, gender roles, religious beliefs, and the like. Understanding our identity and the identity of other people as a dynamic process allows us to constantly change our identity according to our needs, aspirations, expectations, and not according to what the world expects.

An important aspect is that within the outlined paradigm, we allow other people to build their own identities, refraining from stigmatization, social stigma, perception through the prism of stereotypes.

Thus, identity can be defined as belonging to one group and differentiating from others. Depending on the context in which we are, we are constantly reevaluating our identity. For example, a single woman in a male group may have a stronger understanding of gender identity than in a mixed gender group. Therefore, modern researchers turn to the concept of "multiple identities" ${ }^{\prime 31}$.

${ }^{28}$ Salata, G. (2019). Bibliotekoznavstvo, informatsiini nauky ta sotsialna spravedlyvist. Ukrainian Journal on Library and Information Science, 3, 10-18. DOI: http://dx.doi.org/ 10.31866/2616-7654.3.2019.169662.

${ }^{29}$ Ohana, Y. \& Otten, H. (2012). A new intercultural learning concept for the European youth sector? In Ohana, Y., Otten, H. (Eds.). Where do you stand? Intercultural learning and political education in contemporary Europe. Berlin, Germany: VS VS Verlag für Sozialwiessenschaften (pp. 183-240).

${ }^{30}$ Kim, Y. (2009). The Identity Factor in Intercultural Competence. In D. K. Deardorff (Ed.). The Sage Handbook of Intercultural Competence. Thousand Oaks, CA: Sage (pp. 53-65).

31 Danylova, T. (2012). Problema liudskoi identychnosti u postmodernii kartyni svitu. Anthropological Measurements of Philosophical Research, 3, 16-22. 
Although this concept is mainly used to analyse people who have combined different cultural traditions, it can be extended to any person in a changing social context, the "search for the Self" is largely a reaction to the science's confidence in its own efforts to explain the outside world and determine the place of man in this world.

In fact, this is due to the recognition that the reality we perceive is not a "perse" reality, but rather constructed by the mind itself. That is why the postmodern era is very sceptical of the explanations that claim absolute truth. Instead, it focuses on the relativity of truth for each individual.

In the postmodern sense, everything is an interpretation - we create our own reality by interpreting the world around us. Reality arises through our interpretation of what the world means to us personally. Preferring concrete experience over abstract principles, postmodernism argues that the results of one's own experience are relative rather than definitive and universal, and tries to offer a new understanding of man within the discourse ${ }^{32}$.

Identity becomes fluid; it is formed and constantly transformed in ways of representation in the cultural systems that surround us. As S. Hall noted, "within us are contradictory identities, pulling in different directions, so that our identifications are continually being shifted about ${ }^{33}$."

A person's identity is defined both through self-identification (as we identify ourselves) and through hetero-identification (as others identify us). At the individual level, identity is closely related to the need to interact with others, with society as a whole and with the recognition of one's own autonomy. More often, the identity that a person "assigns" differs from the identity that others "attribute" to it.

Even through the prism of the dynamic, constructivist point of view of the postmodern era people often assume that there is only one identity. This type of worldview generates cognitive dissonance, which is extremely dangerous, especially in a globalizing world and growing cultural contacts.

Individuals strive to maintain a positive self-identity and feel safe within their identity. To achieve this, various strategies are used. One is to emphasize the differences between in-groups and out-groups, which can create artificial categorization that emphasizes differences and reduces similarity. This often leads to competition or confrontation, which in some cases causes acts of violence and discrimination.

${ }^{32}$ Danylova, T.V. (2017). Searching for the True Self: The Way of Nondual Wisdom. Anthropological Measurements of Philosophical Research, 12, 7-15. DOI: 10.15802/ ampr.v0i12.119069.

${ }^{33}$ Hall, S. (1992). The Question of Cultural Identity. In S. Hall, D. Held and T. McGrew (Eds.). Modernity and Its Futures. Milton Keynes. Cambridge: Open University Press (pp. 27-316). 
To avoid this dissonance and related problems, to create a narrative congruent, any individual needs to integrate various aspects of his identity in order to feel himself as a unique and full-fledged person ${ }^{34}$. Published by the Council of Europe, the European Manifesto for Multiple Cultural at certain times or at different stages of their lives, people may have different cultural affiliations: "Multiple cultural affiliation is one way of recognising the place of plurality in the face of globalism.

Today's world is fragmented and pluralist, and modern human beings live in different groups, on different levels, and with affiliations of different degrees of intensity, making every social group heterogeneous. Today's European may be conceived in Venice, spend his or her teenage years in Paris, study in Coimbra, get married in Berlin and divorce in London. Where will he or she be buried? Cultural reference systems, that were once fixed and inviolable are now inevitably bound to change in far-reaching ways ${ }^{35}$ ".

Typically, individuals are subjectively identified with more than one social group. In addition, people often use their personal characteristics and interpersonal relationships and social roles as additional components of their own identification. These multiple identifications with social groups, characteristics, relationships and roles help people navigate the world.

For a successful intercultural dialogue, it is necessary to find a balance between accepting one's own identity, recognizing the cultural characteristics of one's group, and tolerant attitudes toward representatives of cultural outgroups.

"...Multiple cultural affiliation is becoming the central pillar of an emerging European citizenship. It makes it possible both to conceive and to experience the complex, differentiated development of cultural identity in mature democratic societies. It firstly recognises communities which bring with them different references in terms of identity, and secondly allows each individual to have a number of specific identities expressed through belonging to various cultures... multiple belonging is perceived as the possibility for everyone, either individually or in a group, to feel simultaneous or successive affiliation with a set of values or cultural references shared by several groups or communities..."36.

${ }^{34}$ Danylova, T. (2015). The Way to the Self: The Novel "Steppenwolf" Through the Lens of Jungian Process of Individuation. Anthropological Measurements of Philosophical Research, 7, $28-35$.

${ }^{35}$ European Manifesto for Multiple Cultural Affiliation. (2007). URL: https://rm.coe.int/ 16806abde8.

${ }^{36} \mathrm{Ibid}$. 


\section{CONCLUSIONS}

The scientific novelty of the work is to justify the feasibility of using the concept of multiple cultural identity in the context of globalization processes, which requires the development of a new paradigm of thinking. In modern conditions, the imperative of social and cultural interaction becomes one's own free choice of cultural affiliation, which encourages the individual to comprehend interpersonal and intergroup interactions from the position of tolerance and makes him or her open to understanding the other identities carriers.

The constructivist approach to understanding the phenomenon of culture, which has become dominant in the postmodern world, has fostered a new interpretation of cultural identity, which is understood as a dynamic process of combining individual and group identities and is not completely finalised.

The symbol is one of the most meaningful concepts in culture. Since it represents the deepest level of culture, its meaning cannot be deciphered in a directly, rationally; on the contrary, it must be experienced and felt "emotionally", gradually deciphering the whole multitude of all its meanings. Symbols carry a deep cultural and semantic load, traced back to the ancient times and reflecting archaic thinking.

Symbols act as a peculiar language and try to answer the most difficult questions of being. They direct thought beyond the individual horizon and acquire a new, unexpected sound, depending on the recipient's understanding. The symbol as a cultural memory accumulator permeates through all cultures, "translating" archetypes into the language of culture, for its interpretation it is necessary to move along the cultural "vertical", trying to understand its primary meanings.

Multiple cultural identity contributes to a person's capacity for change, the ability to cope with new challenges, the globalized world is full of. This ability to adapt is a crucial prerequisite for improving the process of intercultural communication within the new geopolitical construction of the universe. The authors see the prospects for further scientific research in the study of the cultural identification mechanisms; it has important theoretical and practical significance for the formation of a favorable cultural environment.

\section{SUMMARY}

A symbol is one of the most meaningful concepts in culture. Based on the deepest level of culture, its meaning cannot be deciphered directly, rationally; on the contrary, it must be experienced and felt "emotionally", gradually deciphering all its meanings. Symbols carry a deep cultural and semantic load, traced back to the ancient times and reflecting archaic thinking. The 
constructivist approach to culture, being dominant in the postmodern world, contributes to the emergence of a new cultural identity interpretation. It is understood as a dynamic process of combining individual and group identities, considered as fundamentally incomplete. The results of the study concluded the multiple cultural identities contributing to a person's ability to change, the ability to cope with the new challenges of the globalized world. This ability to adapt is an essential prerequisite for improving the process of intercultural communication within the framework of the new geopolitical structure of the world.

\section{REFERENCES}

1. Berry, J.W. (1980). Introduction to methodology. In H.C. Triandis \& J.W. Berry (Eds.). Handbook of cross-cultural psychology, 1. Boston: Allyn and Bacon (pp. 1-28).

2. Burke, P., \& Stets, J. (2009). Identity Theory. Oxford University Press.

3. Collier, M., \& Thomas, M. (1988). Identity in intercultural communication: An interpretive perspective. In Y.Y. Kim \& W.B. Gudykunst (Eds.). Theories in intercultural communication (International and Intercultural Communication Annual), 12. Newbury Park, CA: SAGE 12 (pp. 99-120).

4. Danylova, T. (2012). Problema liudskoi identychnosti u postmodernii kartyni svitu. Anthropological Measurements of Philosophical Research, 3, $16-22$.

5. Danylova, T. (2013). Overcoming the Cultural Differences: Parable as a Means of Intercultural Dialogue. Anthropological Measurements of Philosophical Research, 3, 42-51.

6. Danylova, T. (2015). The Way to the Self: The Novel "Steppenwolf" Through the Lens of Jungian Process of Individuation. Anthropological Measurements of Philosophical Research, 7, 28-35.

7. Danylova, T.V. (2017). Searching for the True Self: The Way of Nondual Wisdom. Anthropological Measurements of Philosophical Research, 12, 7-15. DOI: 10.15802/ampr.v0i12.119069.

8. European Manifesto for Multiple Cultural Affiliation. (2007). URL: https://rm.coe.int/16806abde8.

9. Hall, S. (1992). The Question of Cultural Identity. In S. Hall, D. Held and T. McGrew (Eds.). Modernity and Its Futures. Milton Keynes. Cambridge: Open University Press (pp. 27-316).

10. Intercultural Learning: theories, contexts, realities. (2009). URL: https://pjp-eu.coe.int/documents/1017981/10762748/Ch2.pdf/0b364432-7efb6a45-a4bc-50de19787213. 
11. Jackson, R.L. (1999). The negotiation of cultural identity: Perceptions of European Americans and African Americans. Westport, CT: Praeger.

12. Yunh, C.G. (1991). Arkhetip i simvol. Moscow: Renessans.

13. Kemper, D. (1993). Sociological Models in the explanation of emotion. In M. Lewis \& J.M. Havilland (Eds.). Handbook of Emotions. New York: The Guilford Press (pp. 41-51).

14. Kim, Y. (2009). The Identity Factor in Intercultural Competence. In D. K. Deardorff (Ed.). The Sage Handbook of Intercultural Competence. Thousand Oaks, CA: Sage (pp. 53-65).

15. Losev, A.F. (1995). Problema symvolu ta realistychnoho mystetstva. Moscow: Iskusstvo.

16. Macionis, J. (2005). Sociology. Pearson Prentice Hall.

17. Ohana, Y. \& Otten, H. (2012). A new intercultural learning concept for the European youth sector? In Ohana, Y., Otten, H. (Eds.). Where do you stand? Intercultural learning and political education in contemporary Europe. Berlin, Germany: VS VS Verlag für Sozialwiessenschaften (pp. 183-240).

18. Peoples, J. \& Bailey, G. (2017). Humanity: An Introduction to Cultural Anthropology. Cengage Learning.

19. Pylypiv, V. (2019). Arkhetypni kulturni symvoly ta formuvannia kulturnoi identychnosti ukraintsiv Kanady: do postanovky problemy. National Academy of Managerial Staff of Culture and Arts Herald, 1, 190-194. DOI: https://doi.org/10.32461/2226-3209.1.2019.166907.

20. Salata, G.V., Bachynsjka, N.A. (2019). Kultura i komunikatsiia: yak kultura vplyvaie na spryiniattia informatsii. Bibliotekoznavstvo. Dokumentoznavstvo. Informologhija, 3, 80-87.

21. Salata, G. \& Danylova, T. (2018). The Ecological Imperative and Human Nature: A New Perspective on Ecological Education. Interdisciplinary Studies of Complex Systems, 12, 17-24.

22. Salata, G. (2019). Bibliotekoznavstvo, informatsiini nauky ta sotsialna spravedlyvist. Ukrainian Journal on Library and Information Science, 3, 10-18. DOI: http://dx.doi.org/10.31866/2616-7654.3.2019.169662.

23. Shin, C.I. \& Jackson, R.L. (2003). A review of identity research in communication theory: Reconceptualizing cultural identity. In W.J. Starosta \& G.-M. Chen (Eds.). Ferment in the Intercultural Field: Axiology/Value/Praxis. Thousand Oaks, CA: SAGE (pp. 211-241).

24. Shynkaruk, L., Salata, G. \& Danylova, T. (2018). Dialogue of Cultures: E. Hall and F. Kluckhohn. Academy of Managerial Staff of Culture and Arts Herald, 3, 128-133. 
25. Shynkaruk, V., Salata, G. \& Danylova, T. (2018). My thas the Phenomenon of Culture. Academy of Managerial Staff of Culture and Arts Herald, 4, 17-22.

26. Storozhuk, S.V. \& Hoyan, I.M. (2017). Gender Equality as a Modern Phenomenon. Anthropological Measurements of Philosophical Research, 11, 71-83. DOI: 10.15802/ampr.v0i11.105481.

27. Storozhuk, S. V., Hoyan, Y.N. (2016). Vplyv virtualnoi realnosti na samoaktualizatsiiu tyneidzheriv: antropolohichnyi vymir. Anthropological Measurements of Philosophical Research, 9, 17-28. DOI: 10.15802/ ampr2016/72119.

28. Swidler, A. (1998). Culture and Social Action. In Ph. Smith (Ed.). The New American Cultural Sociology. Cambridge, U.K.: Cambridge University Press (pp. 17-187).

29. Swidler, A. (2003). Talk of Love; How Culture matters. Chicago, Il: University of Chicago Press (pp. 250-285).

30. Tajfel, H. (Ed.). (2010). Social Identity and Intergroup Relations (European Studies in Social Psychology). Cambridge, U.K.: Cambridge University Press.

31. Triandis, H.C. (1995). Individualism and Collectivism (New Directions in Social Psychology). Boulder: Westview Press.

32. Unger, J. (2018). Symbols and Symbolisms in Culture. Papyrus. URL: http://papyrus.greenville.edu/ 2018/02/symbols-and-symbolisms-in-culture.

33. Yep, G.A. (2003). Approaches to cultural identity: Personal notes from an auto-ethnographical journey. In $M$. Fong \& $R$. Chuang (Eds.). Communicating ethnic and cultural identity. Lanham, MD: Rowman \& Littlefield Publishers (pp. 69-81).

\section{Information about the author: Volodymyr Pylypiv,} Candidate of Historical Sciences, Associate Professor, Rector of Kyiv University of Culture, 20, Chyhorina str., Kyiv, 01042, Ukraine http://orcid.org/0000-0001-6548-1405 